\title{
Virginia Woolf's Ecological Writing in Her Novels
}

\author{
Wei Ding*, Xiaoli Wang, Chengxing Li \\ English Department of Humanities and Social Sciences, Heilongjiang Bayi Agricultural University, Daqing, China
}

Email address:

dingwei0508@gmail.com (Wei Ding),diannawang2007@163.com (Xiaoli Wang), chxli2000@126.com (Chengxing Li)

${ }^{*}$ Corresponding author

\section{To cite this article:}

Wei Ding, Xiaoli Wang, Chengxing Li. Virginia Woolf's Ecological Writing in Her Novels. English Language, Literature \& Culture. Vol. 2, No. 1, 2017, pp. 1-4. doi: 10.11648/j.ellc.20170201.11

Received: October 31, 2016; Accepted: March 9, 2017; Published: March 18, 2017

\begin{abstract}
Virginia Woolf's novels focus on the truth of life and present the real form of life, and she has a deep sympathy towards human beings and a strong sense of social responsibility. Her works belong to ecological writing. To explore her novel in the light of eco-criticism, this paper aims at analyzing her harmonious ecological concept as anti-anthropocentrism and idea of equality for all creatures, which will promote the scope of eco-criticism studies and provide a new approach to interpret her works.
\end{abstract}

Keywords: Ecological Writing, Virginia Woolf, Eco-criticism

\section{Introduction}

Virginia Woolf endeavors to present the new form of novels, incorporating the form of music, painting and poetry into the literary creation, and she produces many avant-guarde novels which become classics, thus her keen perception for arts enlarges the vision of stream of consciousness novels. She focuses on presenting the "moment of being" in order to reveal truth in life and true condition of life, which shows that she has a deep concern in human being's fate and a strong sense of social responsibility. Virginia Woolf's ecological perspective in literary creation is based on her artistic pursuit. She advocates that novels should adopt the "modern soul mode" [1], that is to underline the dominant position of people though true presentation of trace of thinking and impersonal characterization, thus surpassing the traditional "personal" expression and exhibiting the universal spiritual condition in the historical context.

Virgina Woolf lived in the late 19th and early 20th century which witnessed the historical changes in politics, economy, society and sciences, and peopl's life mode and ideology changed fundamentally, which was called the beginning of modernism. As one of the central figures in the Bloomsbury Group, Virginia Woolf was under the influence of Cambridge scholars especially Roger Fry and Painter Venessa Bell, and she knew how science had impact on philosophy and artistic criticism. The Britain began the imperial period during that time. Domestically, the income decreased and unemployment became even worse due to the decreasing of the profit of the industry, and the living standard of the workers became worse, which resulted in more and more strikes. At the same time the British began a violent exploitation of the colonies. As the imbalance of the interest among different countries increased, the World War II is impending. Virginia Woolf saw the drive force of the economic interest and power in the capitalist society, and saw clearly the living condition of modern people in which they are isolated with nature and with themselves, so she said "human nature changed in 1910" [2] after she visited the post-impressionist exhibition. The changes here refers to the human relationship. The artists changed the way of presenting the world, they expressed a subjective impression in their works. The painters would rather to emphasize the influence of the light and shadow on the object and not just give the objective reflection of life. The change showed the reconsideration of the relationship between men and their surroundings. Neither the subject nor the object is in the dominant center, meanings are based on the understanding of the dynamic relationship, which is the deconstruction of the concept of center. All these reflect the thought on the central position of man, and on the position of nature.

It is based on this point that Virginia Woolf consider that man and nature are inseparable. In her novels, natural sights and man's emotion echo with each other. In The Waves, the passing of the sun in the sky symbolizes the indifferent time. 
In To the Lighthouse, the lighthouse is the symbol of personal ideal. In Kew Garden, the snail's biological behaviour arouses readers' wild imagination. In Virginia Woolf's point of view, modern people are always surrounded by new things which can change their mood easily. Without knowing the relationship between man and nature, one may get into bewilderment and even despair. Most of Virginia Woolf's works are both experiments in literary forms and response to the thinking on ecological problem.

\section{Natural as the Source for Mutual Understanding}

Ecological thinking in The Waves focuses on the aspect of spiritual ecology. Ecologists considered that the ecological crisis include"the inequality between man and man"and"the deep rooted anti-nature facts in human civilization"apart from"the inequality between man and nature". [3] The author displayed that people can detest other people's subtle feelings through merging with nature. At the beginning of the novel, the visual, listening and inner activity are presented by turn, they sense the existence of each other because of their common feelings, and they can even see through each other's inner activity and understand the meaning of the world to other people. The narration of the novel showed that nature functions as a medium in the communication among people, which can be traced through the characters' growth. Literary critic L. Elizabeth Waller uses the term "ecological dialogue" to describe how in Virginia Woolf's novels "...the human characters engage directly and profoundly with nonhuman characters..." whereas Arnold Berleant, an environmental philosopher, describes the relationship between an individual and their environment, not in separate dualistic terms but rather as a continuum; there is no outside or inside [4].

Bernard holds within himself the ability to tell stories, which resulted from his ability to talk to nature. Bernard is a lover of nature. He is always close to nature, discovers the beauty of nature and has a harmonious relationship with nature, through which he can reach the realm of imagination, and states his feelings freely, and thus has a clear understanding of himself and personal relationship. When Bernard saw that Susan got upset seeing Jenny kissed Luis, he perceived that she put her anger and sadness into her handkerchief, following her to comfort her. He drew Susan's attention to a beetle with a leaf on its back, reminding her that the natural sight can help get rid of the grievance. Susan's jealousy towards Jinny shook off as the beetle tries its best to crawl forwards, which is just like Bernard's words spoken to her inner most and relieve her sadness. In this way, Susan realized that her eyes had become "hard" on one aim because her eagerness to possess, which made her use only simple language to describe what she could see, so she could not get along with other people with rich words as Bernard did. The way Susan understand nature is single and still, and it is a kind of ending; however, Bernard could see a nature full of meaning and inspiration to imagination, which vitalized his gift for language and made him a novelist.

Bernard's sensation of nature does not only give him the ability to tell story, but also grants him the sense of wholeness in existence. He sees himself part of nature, and interacts with nature. When Bernard communicates with others, he can set up the closeness immediately through his words. He always calls this intimate relationship as "domain", "universe", and "world" covered with a mist in its outer. In this intangible world, what is enclosed is the soul that can really communicate. When people merge into nature, the natural objects become real and hard in people's senses. For example, the concept of "big" and "small" changed. When Bernard and Jinny sit in the shade of the beech leaves, the birds take them as a tree lying on the ground, and at this moment they feel that"leaves are high as the domes of vast cathedrals. We are giants, lying here, who can make forests quiver" [5]. Bernard's words gave Jinny perspective to treat all forms of live equal, feeling the real life at that moment, thus not being bothered by the outer world. Jinny realized that "this is here... this is now... My hand is like a snake's skin. My knees are pink floating islands." [6] They entered into a common world of language, reaching the point when they completely understand each other through communication.

\section{The Meaning of Life Through Anti-anthropocentrism}

In the traditional dualism thinking, men and nature are opposite to each other. The two affect each negatively because of anthropocentrism, and the value of people's existence and the law of nature can only operate separately, since they can not communicate with each other. However, in the philosophy of modern ecocentrism, it is considered, "people have to change the living mode under the concept of anthropocentrism in order to eliminate Eco-crisis". [7] In Virginia Woof's novels, the natural objects are enlarged indefinitely and placed in the center, deconstructing the central position of man. The interpretation of nature helps people understand the meaning of life. In Kew Garden, the insignificant snail labored on its way with huge leaves ahead and heavy load on its back provides a clue through the story. Four groups of people with different social background and life experience stop by the garden. Through their words readers can know their state of mind, and they are all stuck in the dilemma and straggling in life. The meaning of life to the people and to the nail are naturally interrelated. Thus the image of snail embodies the equality of all lives, which promote the respect for life. The difficulty of life for the animals can be interpreted from the perspective of man, and man's dilemma in life becomes universal.

When people can treat nature equally, man will not be the ruler and interpreter of the meaning, but part of nature. Literature plays an important part in understanding otherness, whether it is human or nonhuman kind, and Virginia Woolf's The Waves illustrates how the ecological dialogues could be listened to and participated in more profoundly [8]. This is the 
base for a harmonious relationship between man and nature, which is reflected clearly by Rhoda in The Waves. Virginia Woolf considered that people can not feel the real being of oneself living in the physical time. People begin to think about his or her condition when they get stuck, which seems that they stopped at a moment, excluded outside the physical time. Virginia Woolf considered that this moment is important for people to understand the relationship between themselves and the world. As Rhoda said, "look, the loop of the figure is beginning to fill with time; it holds the world in it. I begin to draw a figure and the world is looped in it, and myself am outside the loop; which I now join-so -and seal up and make entire, and I am outside of it, crying, 'Oh, save me, from being blown for ever outside the loop of time!"' [9] This indicates that man is part of nature, however, the natural part of man is always neglected, since they regarded themselves as rulers of nature. People experience the fear of being abandoned by time and nature, only when people are in trouble. The irresistible of the time passing and the powerful natural law can not be changed by human mind. To take an opposite position will make people isolated, which will lead to their own doom. Virginia Woolf's expresses her spiritual ecology in the novels, that is to return to nature and get along well with nature, which is the way people to know their real condition and the meaning of life. This is in line with the definition of "Spiritual Ecology" given by ecologists, "It is a subject on the study of the relationship between the object existing as spirit (mainly refers to man) and living environment (including natural, social and cultural environment). On one hand it is involved in the healthy development of the spiritual object, on the other hand it is about the balance, stability and development of the eco-system under the influence of the spiritual changes."[10]

\section{Nature as a Source for the Growth of Artists}

As a novelist, Virginia Woolf created Orlando, To the Lighthouse, Waves and so on with the growth of the artists as the main plot, telling stories about poet, painter and novelist respectively. They are all close to nature, and even attached to nature, therefore, the inspiration for art resulted from their deep understanding of nature. In Orlando, the hero of the novel composed a piece of poetry as a young man under an oak tree, and he took the poem with him from that time on, revising it from time to time. The style of the poetry changed from simple rhetoric devise in his childhood, to heavy polish in his youth, and to concise in his middle age. He hold on to this poem as if it can protect the poet's sensitive heart. The young man sitting under the oak tree composing will never forget his ambition, no matter being in the royal court favored by the Queen, or got lost in the glacier after the heart beaten by love, or visited many counties as a ambassador, or experienced the mystery change from man to women. That oak tree stands as a pure land, which is the source for growth and the power for being himself. Whenever he got into trouble, Orlando would be eager to return to the oak tree, lying on its huge root to communicate with nature, feeling the real being and absorb inspiration for literary creation. At the end of the novel, Orlando became a middle aged woman, and she buried the poem under the oak tree, which shows that she owed her growth as a poet to the support from nature. "'It's goose!' Orlando cried, 'It's wild goose!'” [11]

Lily the painter intends to have a painting with Mrs. Ramsay as her model in To the Lighthouse. Lily focused on the relationship of different things, which is under the influence of post-impressionist painting. In order to grasp the nature of Mrs. Ramsay, Lily has to know how she gets along with everything around her. To get to the lighthouse symbolizes Mrs. Ramsay's emotional inner heart and her pursuit for harmony, which is the key for Lily to understand her. If the lighthouse is a symbol for Mrs. Ramsay, the sense of order set by the lighthouse is the same as the harmonious relationship kept by Mrs. Ramsay. The sea represents the power of nature, it shows indifference to all things without stopping. As in the second chapter "Time Passes", time is destructive and inscrutable. It is the spirit of Mrs. Ramsay who maintain the whole family: she protects her son James with emotional love, arousing his dream for future; for her husband Mr. Ramsay who is a man worships rationality, she shows sympathy and understanding which he needs. Mrs. Ramsay's love benefits everyone around her, and they all unite together, "their feeling changes immediately, as if it truly took place. They united together in a cave on the island, fighting against the liquid world outside" [12] Her love is like the lighthouse standing in the sea. Although the world changes and natural power is unconquerable, the love of harmony and order can help enlighten people's mind and understand life. Lily could not completely understand Mrs. Ramsay at the beginning, because she was overwhelmed by her powerful famine light. Lily admired Mrs. Ramsay's art in life and her charm, and she could not get rid of her traditional value, at the same time she could not understand Mrs. Ramsay's sympathy to her husband, and that's why she could not complete her painting. Ten year later, after Mrs. Ramsay's death, they came to the island again, and Mr. Ramsay finally reached the lighthouse to realize Mrs. Ramsay's life-long will. Upon this moment, Lily got the true meaning of Mrs. Ramsay's spirit, and draw her last line in the center of the canvas, saying to herself, "I had my vision." [13] The inspiration of her design came from her realization from her understanding of the relationship of all the elements in the nature, which is the base of impressionist writers for their pursuit of structure. Her art is true to life with the aesthetic beauty.

\section{Conclusion}

In Virginia Woolf's times, the systematic ecological awareness has not been formed. However, the destruction of the WWI and the depression caused by industrialization showed the imbalance between the society and natural environment, which is also reflected in the relationship between man and society and in man's spiritual ecology. The modernity in the modern society forms "the conflict between 
nature and man, and the degeneration of the belief represented by God.[14] As an avant-garde writer and important member of Bloomsbury, Woolf knows clearly the powerlessness of modern people, and the waste land caused by the depressed human nature. Therefore, balance, harmony and infusion are the highlighted themes in her novels.

According to Virginia Woolf, nature is the home to human spirit, and a refuge for man's emotion. Understanding nature will lead to true communication among people. However, nature is cruel, it is devastating to human civilization. People have to follow the law of nature in order to withstand its destruction. Virginia Woolf's works are permeated with such ecological thinking. She exchanges man's perspective with animals' to observe the world, thus she tries to show that both the natural need of human beings and other living being should be respected and satisfied. Every individual should get in to the community and communicate. Only every one of human beings remains kind and keeps to the social moral, maintains the harmony in the society, can humankind keep developing.

From the perspective of ecology, one can see Virginia Woolf's strong ecological thinking. It is valuable to analyze her anti-anthropocentrism and equality of all living beings. Besides, ecologists' interpretation on her non-environmental modernism and ecological criticism enlarged the scope of ecological criticism, thus revealed the value of "non-environmental" literary tradition and the value of the classic authors. [15] All these show that Virginia Woolf's writing deserves more ecological analysis.

\section{Acknowledgements}

This work was supported by Program for Humanities and Social Sciences of Heilongjiang Province (13E050), The Influence of Virginia Woolf's Novels on the Development of British Ecological Literature.

\section{References}

[1] Qu, Shijing. Virginia Woolf and her Art of Fiction. Shanghai: Shanghai Literature and Art Press, 1989.

[2] Woolf, Virginia. Common Reader. London: Mariner Books, 2002.

[3] Hu, Zhihong. Study on Western Ecological Criticism [M]. BeiJing: China Social Science Press, 2000, pp. 44.

[4] Berleant, Arnold, ed. Environment and the Arts. Aldershot: Ashgate, 2002. Print, pp 6-7.

[5] Woolf, Virginia. The Waves. Hertfordshire: Wordsworth Editions Limited, 2000, pp. 32.

[6] Hu, Zhihong. History of Western Ecological Criticism. Beijing: People's Press, 2015, pp. 12.

[7] Woolf, Virginia. The Waves. Hertfordshire: Wordsworth Editions Limited, 2000, pp. 12.

[8] Swanson, L. Diana. "Woolf's Copernican Swift: Nonhuman Nature in Virginia Woolf's Short Fiction." Woolf Studies Annual 18 (Annual 2012): Literature Resource Center: Pace University Press, 2012. 53-74. Web. March 2013, pp. 54.

[9] Woolf, Virginia. The Waves. Hertfordshire: Wordsworth Editions Limited, 2000, pp. 19.

[10] Lu, Shuyuan. Scope for Ecological Criticism. Shanghai: Southeast Normal University Press, 2006, pp.1330-1352.

[11] Woolf, Virginia. Orlando. London: The Hogarth Press, 1928, pp. 295.

[12] Woolf, Virginia. To the Lighthouse. London: Penguin, 1996, pp. 86

[13] Woolf, Virginia. To the Lighthouse. London: Penguin, 1996, pp. 185.

[14] Wang Nuo. Ecological Criticism in Europe and America. Shanghai: Xuelin Press, 2008, pp 88.

[15] Hu, Zhihong. History of Western Ecological Criticism. Beijing: People's Press, 2015, pp. 313. 